\title{
Sex Determination of Bovine Embryos Based on Embryonic Cleavage Rates
}

\author{
By Birthe Avery, Mette Schmidt and Torben Greve \\ Department of Reproduction, \\ Royal Veterinary and Agricultural University, Copenhagen, Denmark.
}

\begin{abstract}
Avery, B, M. Schmidt and T. Greve: Sex determination of bovine embryos based on embryonic cleavage rates. Acta vet. scand. 1989, 30, 147-153. - Bovine embryos $(n=64)$ collected at day- 6 from 10 superovulated and inseminated donors were evaluated upon recovery and again after incubation for approx. $12 \mathrm{hrs}$. According to cleavage rate they could be divided into a fast, an intermediate and a slow developing group, respectively. This grouping was correlated to embryonic sex determined by karyotyping $(n=29)$. From the fast developing group we found 7 males and 2 females (male ratio $78 \%$ ), from the intermediate group 3 males and 8 females (male ratio $27 \%$ ) and from the slow group 1 male and 8 females (male ratio $11 \%$ ). From this preliminary study it is concluded that the rate of embryonic development may be used as a sex discriminator.
\end{abstract}

sex ratio; cattle; karyotyping; fast and slow developing embryos.

\section{Introduction}

Embryos recovered at day-6 from superovulated cattle often are at various developmental stages within the same flushing. This could be due to asynchronous ovulations, variation in time of fertilization and/or to an inherent difference in cleavage rate and thus development of the individual embryo.

This last aspect was substantiated by Tsonoda et al. (1985) who cultured 8-cell mouse embryos $(n=247)$ to the blastocyst stage. During the culture period they were separated in chronological order based on the time when the first blastocoele was seen. After development they were divided into 3 groups according to the time of blastocoele formation and transferred to foster mothers with the following result: from the fastintermediate- and the slow developing group the percentages of males were $71 \%, 44 \%$ and $20 \%$, respectively.

A clear relationship between the rate of embryonic development and sex ratio of the offspring was found also in cattle by Itoh \& Goto (1986). The percentages of males from the 3 developmental groups were $77 \%, 40 \%$ and $24 \%$, respectively.

By examining day 9 mouse embryos $(n=67)$ at the neurulation stage, Seller \& PerkinsCole (1987) found similar results. The mouse embryos were arranged according to somite number, followed by sex chromatin examination of the yolk sac. They found the following percentages of males in the 3 groups: $94 \%, 45 \%$ and $25 \%$, respectively.

These 3 reports suggest that embryo development might be used as a mean of embryo sexing in the embryo transfer industry, especially for those donor animals that give several embryos per flushing. Such method would be non-invasive, cheap and easy to perform, and its accuracy seems to be in the same order of magnitude as other sexing methods.

It was the purpose of the present small experiment to reveal a possible relationship be- 
tween the rate of embryonic development and sex ratio in superovulated cattle.

\section{Materials and methods \\ Embryo collection}

Dairy cattle were superovulated either with 1500-2200 I.U. PMSG (Antex ${ }^{\circledR}$, Leo) or $40-50 \mathrm{mg}$ FSH given twice daily in decreasing doses. At $60 \mathrm{~h}$ following the initial gonadotrophin injection, heat was induced with $0.5 \mathrm{mg}$ cloprostenol (Estrumat Vet, Coopers), and AI was performed approximately 12 and $24 \mathrm{~h}$ after onset of standing heat. Embryos were collected at day- 6 after estrous by flushing, either non surgically or after slaughter. The morphological evaluation of the embryos was based on development stages CM: (compact morula), YB: (young blastocyst), BL: (blastocyst), EB: (expanding blastocyst), XB: (expanded blastocyst) and quality: A (excellent), B (good), C (fair), D (poor) (Lindner \& Wright 1983).

\section{Embryo culture}

Embryos were cultured in Hams F-10 culture medium (Flow) supplemented with glutamin $4 \mathrm{mM}$, penicillin $200 \mathrm{IE} / \mathrm{ml}$ and streptomycinsulphate $100 \mathrm{IE} / \mathrm{ml}$ or in Dulbeccos PBS (Pharmacy-KVL) containing glucose $1000 \mathrm{mg} / \mathrm{l}$, pyruvate $36 \mathrm{mg} / \mathrm{l}$, BSA $4 \mathrm{~g} / \mathrm{l}$ and kanamycinsulphate $25 \mathrm{mg} / \mathrm{l}$ both medias supplemented with $10 \%$ fetal calf serum (seralab), in Nunc 4-well dishes at $38^{\circ} \mathrm{C}$ in $5 \% \mathrm{CO}_{2} / 95 \%$ air and $100 \%$ humidity.

Embryo development was evaluated every second hour for approximately $12 \mathrm{~h}$ (1-17 h). When blastocele formation was observed, the embryo was transferred to a separate well, until all embryos had been sorted into chronological order according to development.

\section{Karyotyping}

We have essentially used the method described by King et al. (1979) and King (1984). Briefly, the method was as follows: The cells were arrested at the metaphase stages in medium containing colchemid at a final concentration of $0.5 \mu \mathrm{g} / \mathrm{ml}$, added to the medium for the last $2-4 \mathrm{~h}$ of culture (Colchemide $10 \mu \mathrm{g} / \mathrm{ml}$, Gibco). For hypotonic treatment the embryos were transferred to a $0.88 \%$ citrate solution for 3-5 $\mathrm{min}$. During the swelling period it could be observed under the stereomicroscope, how the good quality embryos filled up the entire perivitelline space while damaged or dead embryos showed less pronounced swelling. Following swelling, the embryos were transferred separately in a minimal drop of hypotonic solution to a clean, grease-free microscopic slide. By addition of one drop of methanol: acetic acid (1:1) and air drying (blowing), the zona pellucida would burst, and the dissociated cells be fixed to the slide. Additional fixation was carried out for $24-48 \mathrm{~h}$ in cold methanol: acetic acid $(3: 1)$, followed by staining in Giemsa $4 \%$ for $5-10$ $\min$.

\section{Sex determination}

Identification of the sex chromosomes was done by direct microscopic evaluation under oil immersion $(100 \times)$. The diploid chromosome number for cattle is 60 with a large submetacentric X-chromosome, a small metacentric Y-chromosome and 58 acrocentric chromosomes.

The total number of metaphases per embryo was observed as well as the number of chromosomes in each metaphase. Sometimes the sex could be identified in spite of an incomplete metaphase, i. e., when both sex chromosomes were present or a single $\mathrm{Y}$ chromosome was seen. If the karyotype was incomplete and only one X-chromosome 
was seen, the embryo was registered as not typed.

\section{Experiments and results}

136 embryos were collected from 10 donors and 7 experiments were set up.

Embryos from experiment 1, (2 donors), 6 and 7 showed a range of developmental stages, whereas embryos from experiment 2,3 ( 3 donors), 4 and 5 yielded embryos of identical age. Upon recovery 125 embryos were compacted morulas, 9 young blastocysts and 2 were blastocysts. $36 \%(n=49), 44 \%(n=$ $60)$ and $20 \%(n=27)$ were grade $A, B$ and $\mathrm{C}$, respectively. The embryos were allocated in two groups in such a way that embryo number and quality were comparable. 64 embryos $(C M, n=54, Y B, n=9, B L, n=2)$ were used in this study (group A embryos), while the rest of the embryos $(C M, n=72)$ were used in another study and treated with H-Y antibodies before karyotyping (group B embryos, Avery \& Schmidt 1989).

Following a culture period ranging from 1-17 h, the embryos could be divided into 3 different groups based on development: a fast developing group $(n=22)$, an intermediate developing group $(n=20)$ and a slow developing group $(n=22)$ (Table 1$)$. Karyotyping with accurate sex determination could be performed for $29 / 64(45 \%)$ of the embryos. The male ratio for each group was as follows (Table 2): from the fast developing group $78 \%$ (7 males and 2 females), from the intermediate group $27 \%$ (3 males and 8 females) and from the slow group $11 \%$ ( 1 male and 8 females).

The average male ratio ( $38 \%$ ) was not significantly different from $50 \%$ (binomial analysis, $p=0.26$ ). It was probably due to random variation in the collection and allocation of the embryos, since for group B embryos the opposite effect was seen (male ratio $58 \%$, Table 3 ).
The data from the fast, intermediary and slow groups were treated statistically in order to substantiate the degree of correlation between sex and development.

The chi square test showed a significant deviation from the average male ratio of $38 \%$ (chi square 9.35, $\mathrm{p}=0.009$, DF 2). The strongest trend was seen in the fast group (chi square 6.06, $0.05<\mathrm{p}<0.01$ ), followed by a weaker trend in the slow group (chi square $2.75,0.10<\mathrm{p}<0.05$ ), the male ratio in the intermediate group was not different from the average male ratio (chi square $0.5, \mathrm{p}=0.50$ ).

The use of a chi square test on these data could be criticized since some of the expected observations were less than 5. Because of this, a binomial analysis was also carried out, without change of the conditions. However the number of embryos in each group was small and minor changes in the distribution might change this apparent dependence between sex and development. Further experiments will be necessary before final conclusions can be made.

$55 \%(n=35)$ of the embryos could not be typed. This was essentially due to lack of metaphases or incomplete metaphases, but also to poor preparation or gross chromosomal abnormality. In embryos of quality c ( $n$ $=16$ ) we found 2 haploids, 1 triploid and 1 tetraploid.

The fraction of untyped embryos in the fast, intermediate and slow groups did not differ significantly from each other (chi square 1.1, $\mathrm{p}=0.58$, DF 2), so we decided to omit them from the statistical calculations.

A recent non-surgical transfer of bovine sex selected embryos based on difference in cleavage rate was performed in order to demonstrate the practical use of the method, but the result was inconclusive.

35 embryos $(\mathrm{BL}=6, \mathrm{CM}=29)$ from 3 donors were transferred to 32 recipients. The 
B. Averyet al.

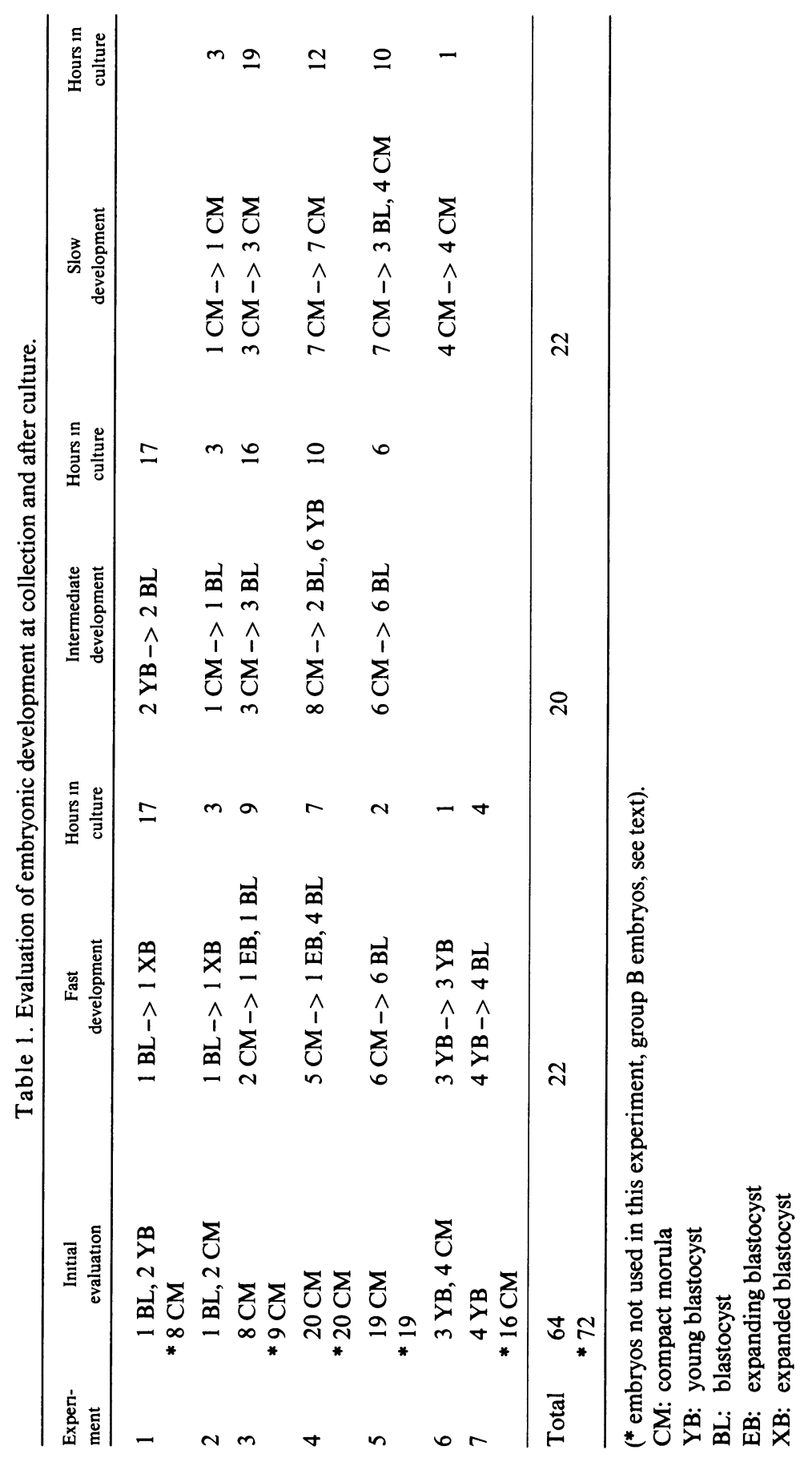


Table 2. Initial number of embryos at collection and the result of karyotyping after allocation into three developing groups.

\begin{tabular}{|c|c|c|c|c|c|c|c|c|c|c|}
\hline \multirow[b]{2}{*}{ Experiment } & \multirow{2}{*}{$\begin{array}{l}\text { Total no } \\
\text { embryos }\end{array}$} & \multicolumn{3}{|c|}{ Fast development } & \multicolumn{3}{|c|}{ Intermediate development } & \multicolumn{3}{|c|}{ Slow development } \\
\hline & & no embryos & male & female & no embryos & male & female & no embryos & male & female \\
\hline 1 & 3 & 1 & 0 & 0 & 2 & 0 & 2 & 0 & 0 & 0 \\
\hline 2 & 3 & 1 & 0 & 1 & 1 & 1 & 0 & 1 & 0 & 1 \\
\hline 3 & 8 & 2 & 2 & 0 & 3 & 1 & 0 & 3 & 0 & 0 \\
\hline 4 & 20 & 5 & 0 & 0 & 8 & 1 & 3 & 7 & 1 & 3 \\
\hline 5 & 19 & 6 & 2 & 1 & 6 & 0 & 3 & 7 & 0 & 1 \\
\hline 6 & 7 & 3 & 1 & 0 & 0 & 0 & 0 & 4 & 0 & 3 \\
\hline 7 & 4 & 4 & 2 & 0 & 0 & 0 & 0 & 0 & 0 & 0 \\
\hline Total & 64 & 22 & 7 & 2 & 20 & 3 & 8 & 22 & 1 & 8 \\
\hline
\end{tabular}

Table 3. Total male ratio for all collected embryos.

\begin{tabular}{lcccccc}
\hline $\begin{array}{l}\text { Embryo } \\
\text { group }\end{array}$ & No embryos & Not typed & Male & Female & $\begin{array}{c}\text { Male }+ \\
\text { female }\end{array}$ & $\begin{array}{c}\text { Male } \\
\text { ratio \% }\end{array}$ \\
\hline A & 64 & 35 & 11 & 18 & 29 & 38 \\
B & 72 & 36 & 21 & 15 & 36 & 58 \\
\hline Total & 136 & 71 & 32 & 33 & 65 & 49 \\
\hline
\end{tabular}

Group A embryos: used in this experiment Group B embryos: not used in this experiment

pregnancy rate of these embryos was much lower than expected. 17 recipients became pregnant with 10 early abortions and one twin abortion on day 98 (sex not observed). 6 calves were born with the following result: from the fast group 2 females, from the intermediate group 1 male and 2 females, and from the slow group 1 female.

These embryos were only cultured $21 / 2-3 \mathrm{~h}$ before transfer in contrast to $12 \mathrm{~h}$ for the karyotyped embryos. Very little development was seen during this period. Further experiments will necessitate more extensive embryo culture, but this may affect the pregnancy rate, since prolonged culture has a negative effect on embryo viability (Renard et al. 1980a, b).

\section{Discussion}

The present work suggests a possible method for sexing preimplantation bovine embryos, based on difference in cleavage rate.

The mechanism behind this sex differentiation between fast and slow developing embryos, where males tend to be more developed than females within the same litter is not known.

A speculative candidate could be H-Y antigen, which is found on male embryos from the 8-cell stage and which can be detected by $\mathrm{H}-\mathrm{Y}$ antibodies. The gene for serological detectable $\mathrm{H}-\mathrm{Y}$ antigen is found on the human chromosome 6 . It is only expressed in males and is thought to be regulated by genes on the $\mathrm{Y}$ - and $\mathrm{X}$-chromosome (reviewed by Wiberg 1987). 
When cultured in H-Y antibody containing medium, the development of male embryos will be retarded. This means that the females will predominantly be blastocysts and the males compact morulas. This is opposite to the method described in this paper, where the male embryos will tend to reach the blastocyst stage before the females.

At its best the method can only be used to predict the sex in the fast and slow developing embryos. It requires a certain period of embryo culture but is otherwise non-invasive.

We do not consider our data to be conclusive, but think that the method deserves further interest.

\section{Acknowledgements}

We want to thank Ms. I. Heinze for excellent technical assistance and Ms. P. Hoffmann for typing the manuscript. This project was funded by The Danish Agricultural and Veterinary Research Council.

\section{References}

Avery $B$, Schmidt $M \cdot$ Sex determination of bovine embryos using $\mathrm{H}-\mathrm{Y}$ antibodies. Acta vet. scand. 1989, 30, 155-164.

Itoh $S$, Goto $T$. Sex frequency of offspring from different developmental stage of cattle embryos. Japanese Journal of Anımal AI Research 1986, 8, 95-99.

King $W A$. Sexing embryos by cytological methods. Theriogenology 1984, 21, 7-17.

King WA, Linares T, Gustavsson I, Bane A: A method for preparation of chromosomes from bovine zygotes and blastocysts. Vet. Sci. Commun. 1979, 3, 51-56.

Lindner GM, Wright $R W$. Bovine embryo morphology and evaluation. Theriogenology 1983, 20, 407-416.

Renard J-P, Heyman Y, Ozll J-P. Importance of gestation losses after non-surgical transfer of cultured and non-cultured bovine blastocysts. Theriogenology 1980a, 13, 109.
Renard J-P, Heyman Y, Ozıl J-P: Importance of gestation losses after non-surgical transfer of cultured and non-cultured bovine blastocysts. Vet. Rec. 1980b, 197, 152-153.

Seller MJ, perkıns-Cole KJ Sex difference in mouse embryonic development at neurulation. J. Reprod. Fert. 1987, 79, 159-161.

Tsonoda $Y$, Tokunaga $T$, Sugle $T$ Altered sex ratio of live young after transfer of fast and slow developing mouse embryos. Gamete Research 1985, 12, 301-304.

Wiberg $U H$. Facts and considerations about sexspecific antigens. Hum. Genet. 1987, 76, 207219.

\section{Sammendrag \\ Kønsbestemmelse af bovine embryoner med forskellig vaksthastighed.}

Formålet med dette pilotforforsøg var at efterprøve om hanfostre vokser hurtigere end hunfostre på embryonalstadiet.

64 bovine embryoner blev opsamlet på dag 6 fra superovulerede og inseminerede køer eller kvier ved ikke-kirurgisk skylning eller fra slagtehusmateriale. Embryonerne som overvejende var på morulastadiet blev bedømt umiddelbart efter opsamling og igen hver anden time under dyrkningen de næste ca. 12 tımer (udviklingsstadium og kvalitet). Dyrkningen blev udført enten i Hams F-10 medium eller Dulbeccos PBS tilsat $10 \%$ føtalt kalveserum (FCS) ved $38^{\circ} \mathrm{C} 15 \% \mathrm{CO}_{2} / 95 \%$ atmosfærisk luft og $100 \%$ fugtighed i Nunc 4-brønds plader. Efter endt dyrkning kunne embryonerne deles i 3 grupper baseret på forskelle i udvıklingsgrad: en hurtı, en intermediær og en langsom gruppe med henholdsvis 22, 20 og 22 embryoner. Fra den hurtige gruppe kunne $9 \mathrm{em}$ bryoner karyotypes med 7 hanner og 2 hunner ( $78 \%$ hanner), fra intermediærgruppen kunne 11 embryoner types med 3 hanner og 8 hunner (27\% hanner) og fra den langsomme gruppe kunne 9 embryoner types med 1 han og 8 hunner $(11 \%$ hanner). Dette forsøg tyder på, at der i de tidlige fosterstadier er forskel på han- og hunembryoners væksthastighed.

Statıstisk ses en sammenhæng mellem udviklingsstadium og køn for ydergruppernes embryoner, men ikke for midtergruppens. 
Desuden blev 35 embryoner fra 3 donorer forsøgt udviklingssorteret efter dyrknıng i $21 / 2$ time og overført til 32 recipienter. Det resulterede i 6 kalve med 2 hunner 1 den hurtige gruppe (forventet hanner), 1 han og 2 hunner i intermediærgruppen og 1 hun i den langsomme gruppe (forventet hunner).
Om metoden kan udnyttes 1 praksis til forudbestemmelse af kalves køn i forbindelse med superovulation og AI hos kvæg kan ikke afgøres på grundlag af ovenstående, men kun efter yderligere forsøg.

(Recelved January 1, 1988, accepted August 11, 1988)

Reprints may be requested from: B. Avery, Department of Reproduction, Royal Veterinary and Agricultural University, 13 Bülowsvej, DK-1870 Frederiksberg C, Denmark. 
